\title{
Impact of selective logging and an intensive line planting system on runoff and soil erosion in a tropical Indonesian rainforest
}

\author{
H. Suryatmojo ${ }^{1}$, F. Masamitsu ${ }^{2}$, K. Kosugi ${ }^{1} \&$ T. Mizuyama ${ }^{1}$ \\ ${ }^{1}$ Laboratory of Erosion Control, Division of Forest and Biomaterials \\ Science, Graduate School of Agriculture, Kyoto University, Japan \\ ${ }^{2}$ Educational Unit for Adaptation and Resilience for a Sustainable \\ Society, Center for the Promotion of Interdisciplinary Education and \\ Research, Kyoto University, Japan
}

\begin{abstract}
Tropical forest management with selective logging and an intensive line planting system are expected to change the hydrological cycle. This study was conducted in a natural tropical rainforest of Central Kalimantan, Indonesia. Direct runoff and soil erosion were studied at three small catchment plots, a virgin forest catchment, a 1-year-old line plantation (2008 catchment) and a 10-year-old line plantation (1999 catchment). Direct runoff in the virgin forest catchment was $13.5 \%$ of precipitation. In the 1999 catchment and 2008 catchment, direct runoff was $31.1 \%$ and $19.7 \%$ of precipitation, respectively. The direct runoff rate in the 1999 catchment and 2008 catchment was 2.3 and 1.46 of the virgin forest catchment, respectively. Average soil erosion in the virgin forest catchment, the 1999 catchment and the 2008 catchment was $10.01 \mathrm{~kg} \mathrm{ha}^{-1}, 19.51 \mathrm{~kg} \mathrm{ha}^{-1}$ and $25.83 \mathrm{~kg} \mathrm{ha}^{-1}$, respectively. The 2008 catchment had the highest soil erosion rate at 2.58 of the virgin forest catchment. The 1999 catchment had a rate of 1.95 of the virgin forest catchment. The implementation of a forest management system should consider the impact of runoff and soil erosion. Controlling human erosional activities and finding ways to combine ecologically based vegetation structure design and soil erosion control techniques would be an effective way to control runoff and soil erosion.
\end{abstract}

Keywords: selective logging, intensive line planting, virgin forest, logged over forest, direct runoff, soil erosion, vegetation structure, soil erosion control. 


\section{Introduction}

One key resource from tropical rainforests is forest timber. However, timber extraction using heavy machines destroys the soil structure that plays an important role in water and nutrient cycling, accelerating the soil erosion rate [17]. Heavy machines in timber collection areas and on skidder roads increase soil compaction by up to $40 \%[17,18]$, and $10-30 \%$ of the soil surface may be laid bare in the form of logging roads, skidder tracks and log landings [3, 28]. In a previous study, the infiltration capacity of a tropical rainforest 1 year after TPTII [Tebang Pilih dan Tanam Indonesia Intensif] treatment decreased to $81.8 \%$ of that of a virgin forest [23]. The use of heavy equipment tends to compact topsoil, setting in motion a negative spiral of reduced infiltrability and increased frequencies of overland flow and sheet erosion, thereby hindering the establishment of a new protective layer of vegetation and litter [28].

Different land use practices affect the infiltration rate of soil in different ways, depending on their effects on the intrinsic properties of the soil [19], and selective logging and intensive line planting systems are suspected to dramatically impact soil. The effect of human activities on runoff regimes has been proven by a number of experimental studies from various parts of the world. Much research has focussed on monitoring the influence of changes in land cover, mainly deforestation and afforestation processes $[4,5,11,26]$, the influence of cultivated areas $[13,15,20]$ and the impact of logging $[6,22,28]$.

Many studies have considered runoff and soil erosion of plots with different land cover, but information on the direct impact of selective logging and intensive line planting in tropical rainforests remains limited. Therefore, in this study, we quantified and compared the direct runoff and soil erosion among virgin forest and two line plantations.

\section{Methods}

\subsection{Study site}

This study was conducted in tropical rainforest at the Sei Seruyan block of Sari Bumi Kusuma company concession area, a private forest in Central Kalimantan, Indonesia $\left(00^{\circ} 36^{\prime}-01^{\circ} 10^{\prime}\right.$ southern latitude and $111^{\circ} 39^{\prime}-112^{\circ} 25^{\prime}$ eastern longitude). This location is part of the high-biodiversity area known as the "Heart of Borneo". The study site was located in the headwater region of the Katingan watershed, one of largest watersheds in Central Kalimantan (Fig. 1). The Katingan watershed has a total catchment area of 1,908,297 ha and the length of the main river is 650 kilometres. This location is approximately $400 \mathrm{~km}$ northwest of Palangka Raya, the provincial capital of Central Kalimantan, and approximately $500 \mathrm{~km}$ east of Pontianak, the provincial capital of West Kalimantan. The forest cover in this watershed is $1,179,985$ ha or $61.83 \%$ of the total area, most of which is found in the headwaters. This upstream catchment is a hilly region with an altitude ranging from 150 to $1,278 \mathrm{~m}$ above sea level. 


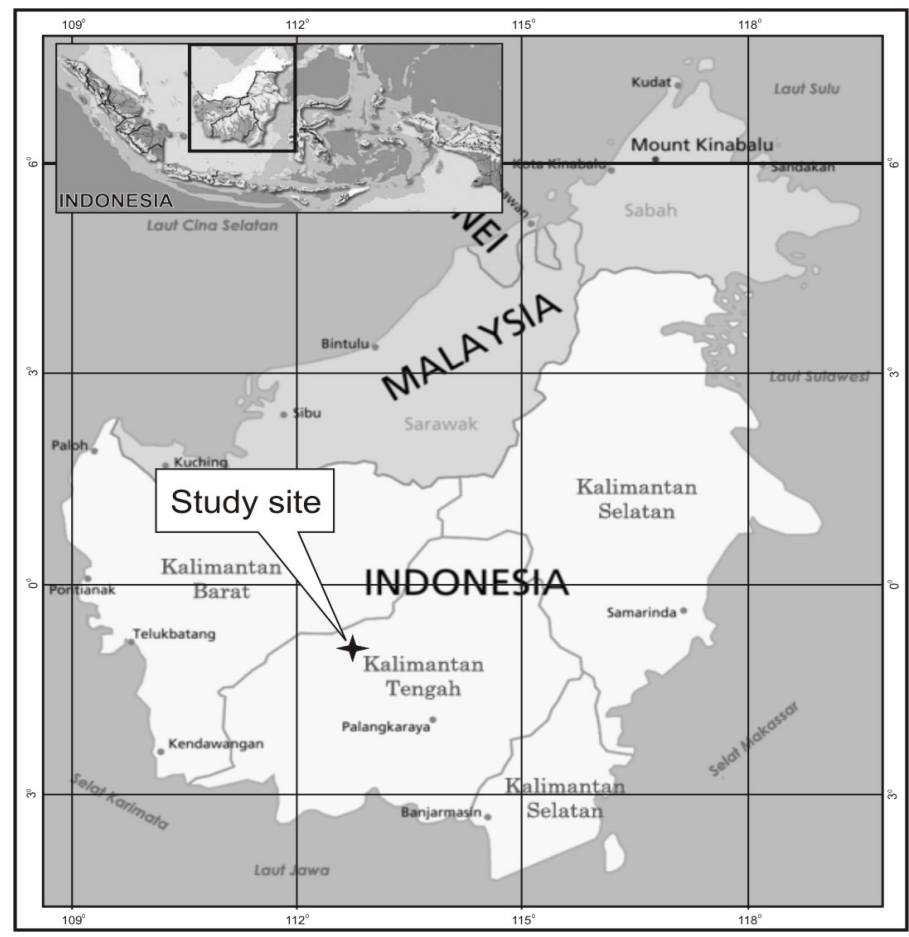

Figure 1: Study site in central Kalimantan.

According to the Schmidt and Ferguson forest climate classification system, the area is a type A (very wet) tropical rainforest (monthly average rainfall $>100$ $\mathrm{mm}$ ) [24]. The mean annual precipitation for the period 2001-2009 was 3,601 $\mathrm{mm}$, with the highest average monthly precipitation $(367 \mathrm{~mm})$ occurring in November and the lowest average monthly precipitation $(183 \mathrm{~mm})$ occurring in August. The number of rainy days varies from 95 to 112 days, and the mean temperature is $30^{\circ} \mathrm{C}-33^{\circ} \mathrm{C}$ at noon and $22^{\circ} \mathrm{C}-28^{\circ} \mathrm{C}$ at night.

The vegetation in Kalimatan is dominated by Shorea spp., Eugenia spp., Eusideroxylon zwageri, Shorea laevis, Calophyllum inophyllum, Litsea firma, Anthocephalus chinensis, Macaranga hypoleuca, Durio lissocarpus and Octomeles sumatrana. The average number of trees is 228 per hectare.

Based on USDA classification, the soil which is classified as Ultisol, remains continuously moist. Ultisol is the most weathered type of soil, and it shows the ultimate effects of leaching. Ultisol is characterized by mineral soil with a $\mathrm{B}_{2}$ horizon with $20 \%$ more clay than the upper $\mathrm{B}_{1}$.

\subsection{Silviculture system in a tropical rainforest}

In Indonesia, selective logging and intensive line planting, or Tebang Pilih Tanam Indonesia Intensif (TPTII), started in 2002. The intensive line planting is implemented after selective logging of about $25 \%$ of the forest; the rest $(75 \%)$ is 


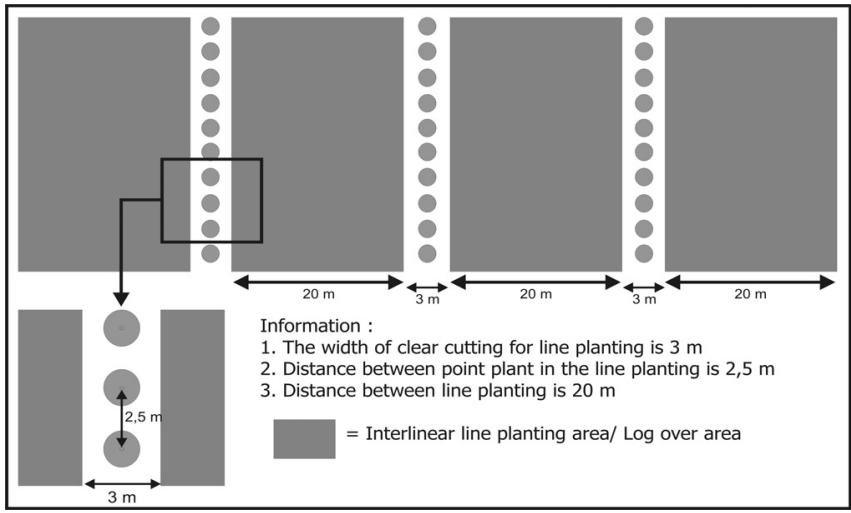

Figure 2: $\quad$ Scheme of plantation in the TPTII system.

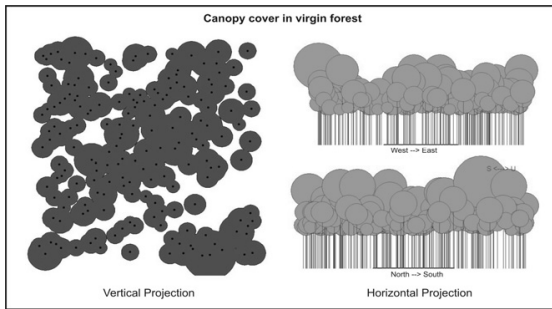

(a)

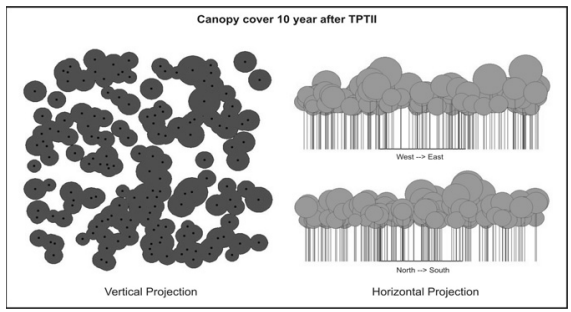

(c)

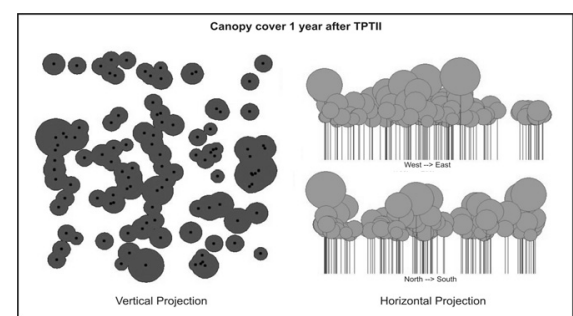

(b)

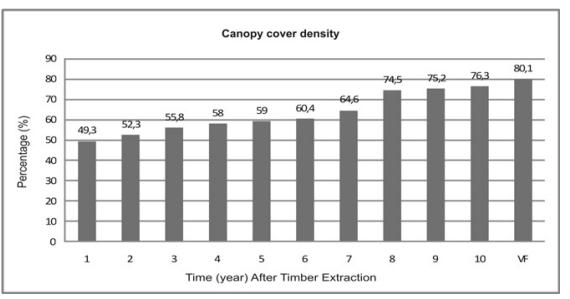

(d)

Figure 3: Canopy cover in virgin forest and after TPTII implementation: (a) virgin forest; (b) 1 year after TPTII; (c) 10 years after TPTII; and (d) percentage of canopy cover density 1-10 years after TPTII.

maintained in its natural condition for biodiversity purposes. The scheme of the TPTII system is shown in Fig. 2.

Typically, about 200 seeds per hectare are planted, and the expected standing stock at the end of the rotation ( 30 years) is around $400 \mathrm{~m}^{3}$ per hectare, assuming 160 trees per hectare with an average diameter of 50 centimetres (or $2.5 \mathrm{~m}^{3}$ per tree) [16]. The changes in canopy cover in the study area as virgin forest was selectively logged and intensively line planted are shown in Fig. 3.

TPTII implementation decreased the number of trees per hectare. In the virgin forest, the percentage of canopy cover was $80.1 \%$. After selective logging and 
intensive line planting, it decreased to $49.3 \%$ [24]. Thus, the implementation of TPTII decreased the canopy cover by $38.5 \%$.

\subsection{Research catchment}

This research was conducted at three small catchments with different forest canopy cover densities: a virgin forest, a1-year-old line plantation, and a 10year-old line plantation. Hereafter, these catchments are referred to as the "virgin forest catchment", the "2008 catchment" and the "1999 catchment", respectively. The catchment areas of the three were 110.33, 191.54 and 149.49 hectares, respectively.

\subsection{Field observation and analysis}

A weir and a water level logger with a logging time of 15 min were installed at each catchment outlet. Rainfall data were collected from a weather station located in the centre of the three catchments. Rainfall calibration data were obtained by comparing ombrometer measurements at three weather stations belonging to a forest timber company. Water discharge was measured by a current meter. Suspension was measured by a suspended sampler. During the research period (June 2009-June 2010), we selected several paired of rainfall and hydrograph data at each catchment. We found 24 paired data in the virgin forest catchment, 35 paired data in the 1999 catchment and 30 paired data in the 2008 catchment. We separated the discharge hydrograph data into direct runoff and baseflow using a straight-line method.

Furthermore, we calculated the direct runoff volume for each hydrograph. The percentage of direct runoff was calculated using Eqn. (1):

$$
\mathrm{DR}_{\mathrm{i}}=\frac{\mathrm{DRO}_{\mathrm{i}}}{\mathrm{P}_{\mathrm{i}}} \times 100
$$

where $\mathrm{DR}_{\mathrm{i}}$ is direct runoff at event $\mathrm{i}, \mathrm{DRO}_{\mathrm{i}}$ is the total volume of direct runoff at event $\mathrm{i}(\mathrm{mm})$ and $\mathrm{P}_{\mathrm{i}}$ is cumulative rainfall at event $\mathrm{i}(\mathrm{mm})$. The direct runoff rate was calculated by comparing the average direct runoff in the 1999 catchment and the 2008 catchment to the average direct runoff in the virgin forest catchment, per Eqn. (2):

$$
\mathrm{DR}_{\text {rate (year.ca) }}=\frac{\overline{\mathrm{DR}_{(\text {year.ca })}}}{\overline{\mathrm{DR}}_{\mathrm{VF}}}
$$

where $\mathrm{DR}_{\text {rate (year.ca) }}$ is the direct runoff rate in the catchment, $\overline{\mathrm{DR}}_{\text {(year.ca) }}$ is the average direct runoff in the catchment and $\overline{\mathrm{DR}}_{\mathrm{VF}}$ is the average direct runoff in the virgin forest catchment. The soil erosion rate was calculated by comparing the average soil erosion in the 1999 catchment and the 2008 catchment to the average soil erosion in the virgin forest catchment, per Eqn. (3):

$$
\mathrm{SE}_{\text {rate (year.ca) }}=\frac{\overline{\mathrm{SE}}_{(\text {year.ca })}}{\overline{\mathrm{SE}}_{\mathrm{VF}}}
$$


where $\mathrm{SE}_{\text {rate (year.ca) }}$ is the soil erosion rate in the catchment, $\overline{\mathrm{SE}}_{\text {(year.ca) }}$ is the average soil erosion in the catchment and $\overline{\mathrm{SE}}_{\mathrm{VF}}$ is the average soil erosion in the virgin forest catchment.

\section{Results and discussion}

\subsection{Runoff characteristics}

As shown in Fig. 4, the total direct runoff was lowest in the virgin forest catchment, and highest in the 1999 catchment $(48.47 \mathrm{~mm}$ ), which was only slightly higher than that in the 2008 catchment. Accordingly, the average direct runoff (and percentage of rainfall as runoff) in the virgin forest, 2008 catchment and 1999 catchment was $3.97 \mathrm{~mm}(13.47 \%), 7.2 \mathrm{~mm}(22.56 \%), 8.7 \mathrm{~mm}$ $(34.65 \%)$ respectively. Hence, the direct runoff rate in the 1999 catchment and 2008 catchment was 2.3 and 1.46 times that of the virgin forest catchment, respectively.

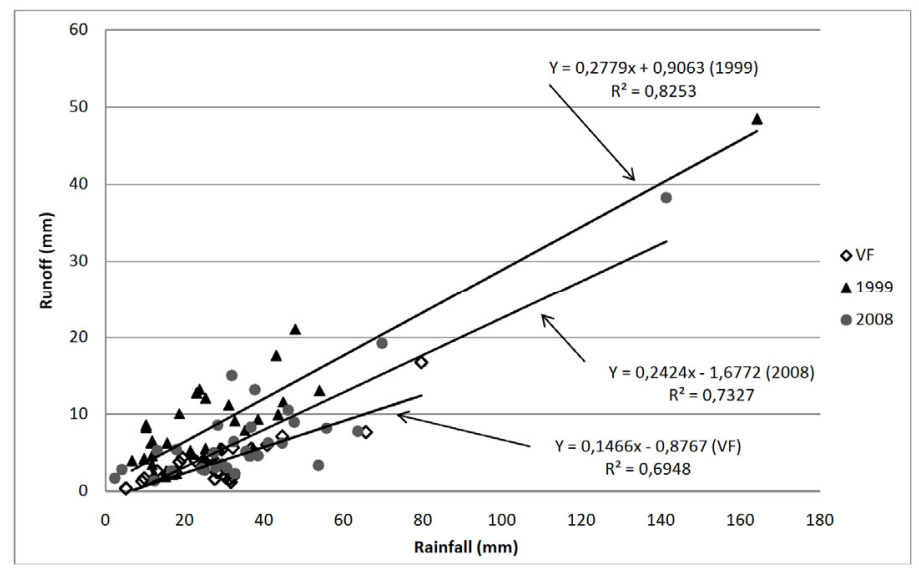

Figure 4: Relationship between rainfall amounts per event and direct runoff.

Canopy cover density in the virgin forest catchment and 1999 catchment were much higher than that in the 2008 catchment at $80.1 \%, 76.3 \%$ and $49.3 \%$, respectively (Fig. 3d). In the virgin forest catchment, vegetation structure is dominated by trees. Minimum sunlight under canopy trees allows limited growth of understory vegetation such as saplings (shrubs) and seedlings. Rainfall in this catchment is captured and stored in the canopy as rainfall interception. The 2008 catchment has less canopy density because of logging activities, and thus there is more open space and more light for understory vegetation to grow and change the vegetation structure more rapidly. Abdulhadi et al. [1] reported that in their study area about 6 months after logging, bare ground was heavily invaded by pioneer species. The shrubby cover softened the physical impact of the raindrops on the soil surface in the catchment and diminished the surface runoff [7]. 
Variation in the vegetation structure in the 2008 catchment increased forest floor cover. This may have increased forest floor retention and thus decreased surface runoff, explaining why the direct runoff in the 1999 catchment was slightly higher than that in the 2008 catchment.

\subsection{Discharge of suspended sediment and soil erosion}

Fig. 5 shows the relationship between water discharge and suspended discharge. The suspended discharge was significantly higher in the 2008 catchment than in the virgin forest and 1999 catchments.

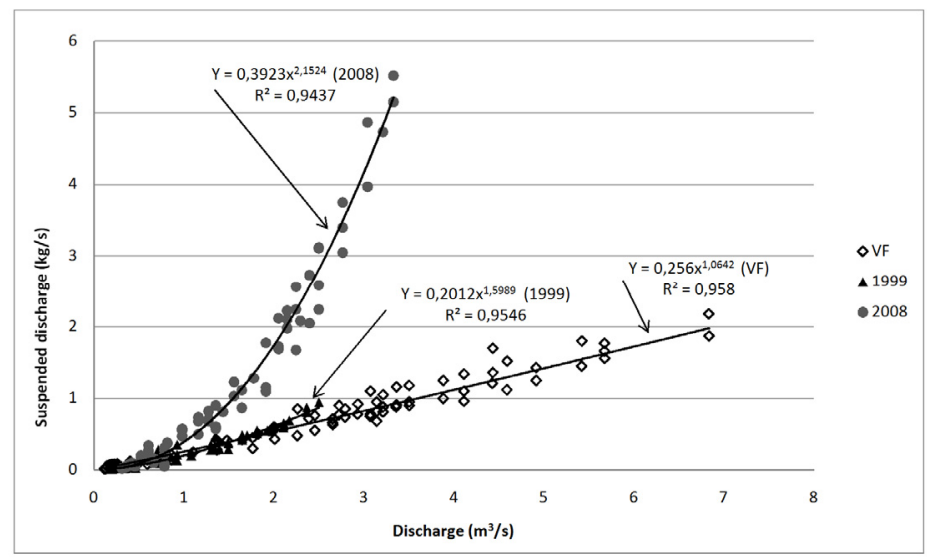

Figure 5: Discharge of suspended sediment in the three catchments.

Fig. 6 shows the relationship between direct runoff and soil erosion in the three catchments. There was a strong relationship between the two, and soil erosion was significantly higher in the 2008 catchment $\left(25.83 \mathrm{~kg} \mathrm{ha}^{-1}\right)$ than in the $1999\left(19.51 \mathrm{~kg} \mathrm{ha}^{-1}\right)$ and virgin forest $\left(10.01 \mathrm{~kg} \mathrm{ha}^{-1}\right)$ catchments. The highest soil erosion value in the 2008 catchment was $338.18 \mathrm{~kg} \mathrm{ha}^{-1}$ for $141.25 \mathrm{~mm}$ of rainfall.

Toy et al. [25] reported that the four environmental factors that determine water erosion and sedimentation are climate, soil, topography and land use. In our catchments, soils in timber logging areas have been impacted by the mechanisation of harvesting operations, which have led to increased compaction, less surface cover, increased rain splash and more direct soil loss.

Forest management by selective logging and intensive line planting using mechanical techniques has changed the canopy density, vegetation structure, soil compaction, soil structure and infiltration capacity of the study site. These destructive activities have caused the forest soil to become brittle and more susceptible to erosion. The amount of suspended sediment in the 1999 catchment was similar to that in the virgin forest catchment, which may be attributable to the nearly equal canopy densities of the two catchments (Fig. 3d). Previous 


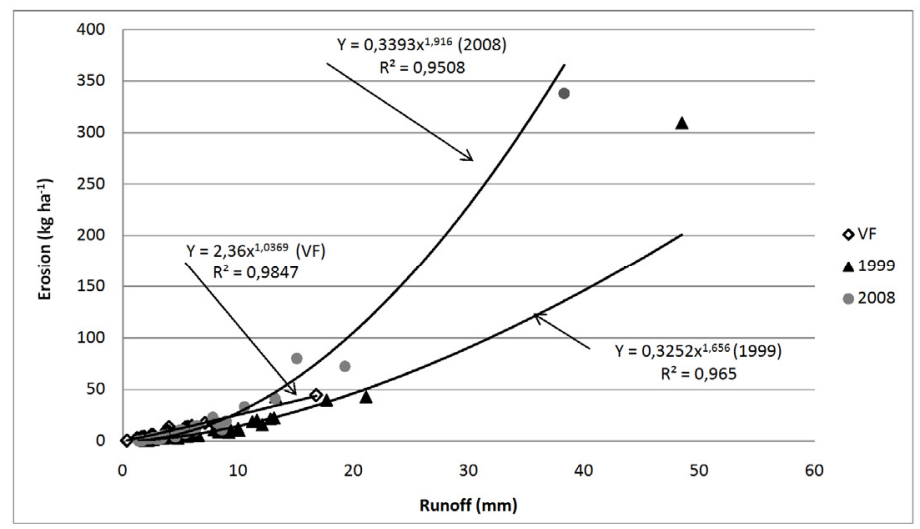

Figure 6: Relationship between direct runoff and soil erosion.

studies reported that reduced rain splash due to vegetation cover leads to less soil loss $[2,6]$. The high density of canopy cover in the 1999 catchment may have also increased rainfall interception, reducing rain splash and thus soil loss.

These results show that changes in forest cover and the physical properties of soil significantly affect the response to rainfall, especially regarding soil erosion and sediment discharge into river channels. Forest managers should consider these conditions, especially in the early years after logging.

\subsection{Effects of forest management system on runoff and soil erosion}

Selective logging and intensive line planting significantly increase direct runoff and soil erosion. The average direct runoff was $13.5 \%$ of rainfall in the virgin forest catchment, but $31.1 \%$ and $19.7 \%$ in the 1999 and 2008 catchments, respectively. The direct runoff rates in the 1999 and 2008 catchment were 2.3 and 1.46 times that of the virgin forest, respectively. The 2008 catchment had the highest soil erosion with a rate that was 2.58 times that of the virgin forest catchment. The 1999 catchment had slightly less soil erosion, with a rate of 1.95 times that of the virgin forest catchment.

Erosion is one of the most serious problems in the tropical rainforest of Kalimantan. Soil organic matter in the Kalimantan forest is very shallow, at about 2-5 cm [27]. Timber extraction and logging takes away forest cover and exposes surface soils. The effects of logging on soil properties can be very profound, especially if logging is conducted with heavy equipment. Erosion control initiatives should be implemented immediately, followed by vegetation restoration. Ruslan and Manan [21] reported that in their study area in South Kalimantan, erosion and surface runoff decreased after skidding roads were abandoned, and trees, grasses and shrubs re-colonised bare ground. However, such secondary forest cover does not protect soil the way primary forest does, nor can it easily compensate for the physical damage already done to the soil (i.e., compaction, loss of soil structure and removal of organic litter) [22]. 
The application of selective logging and intensive line planting has dramatically changed soil compaction, soil structure and infiltration capacity. In our study area, these changes were compounded because of the soil type, fragile soil of the humid tropics called Ultisol. In the humid tropics, poor soil cohesion, high rainfall and high temperatures give rise to highly erosive soils that are very sensitive to the impacts of heavy machinery and the clearance of vegetation cover [8-10, 14]. In addition, Ultisol is acidic and its acidity decreases with soil depth, making it more susceptible to disruption. These soil characteristics made our study area more sensitive to logging and line planting, which in turn augmented runoff and erosion. High rainfall intensity leads to high rainfall erosivity, as the organic soil layer is easily eroded, decreasing soil fertility. Once a forest or even a small patch of forest is cleared, organic matter within the soil is quickly lost. With the disappearance of soil organic matter, the ability of soil to recycle nutrients is also quickly lost, soil fertility rapidly declines and the ecosystem loses its productive capacity $[12,15]$.

The role of vegetation structure starts with its interception of rainfall. The rainfall interception (rainfall-direct runoff) in the virgin forest catchment, 1999 catchment and 2008 catchment was $86.53 \%, 68.95 \%$ and $80.33 \%$ of rainfall, respectively. As these results indicate, rainfall interception capacity was influenced by the dynamic composition of vegetation structure.

The degree to which the canopy affects erosion depends on the percent of the forest floor covered by the understory and the density of the canopy [25]. More understory and denser canopy cover lead to greater rainfall interception and retention. Although canopy density in the 2008 catchment was lower than in the 1999 catchment, the former had more understory vegetation, leading to more rainfall interception.

Our results suggest that a combination of canopy cover and understory has a significant role in controlling runoff and soil erosion.

\section{Conclusion and recommendations}

We found that selective logging and intensive line planting system in a tropical rainforest significantly increase runoff and soil erosion. Such a forest management system has the potential to change not only vegetation structure, but also soil structure, compaction and infiltration capacity as well as forest nutrients as organic litter is removed. Forest land cover was a main factor determining the differences in runoff and soil erosion among the three catchments. Runoff and soil erosion were significantly greater in the 1999 and 2008 catchments than in the undisturbed forest of the virgin forest catchment. This paper demonstrates that forest cover decreases runoff and soil erosion. Proper protection of the forest floor with plant cover under canopy trees would help control runoff and soil erosion.

Forest managers thinking about implementing the TPTII system in tropical rainforests should consider the impact of runoff and soil erosion, especially in the early years after logging and line planting. A proper system of monitoring would allow more direct associations to be made between management practices 
and their impacts on runoff and soil erosion, thereby enabling the identification of problems so that managers can take appropriate preventive measures to improve management. We recommended controlling human erosional activities and combining ecologically based vegetation structure design and erosion control techniques for the effective control of runoff and soil erosion.

\section{References}

[1] Abdulhadi, R., Kartawinata, K., and Sukardjo, S., Effects of Mechanized Logging in the Lowland Dipterocarps Forest at Lempake, East Kalimantan. The Malaysian Forester 44, pp. 407-418, 1981.

[2] Anderson, S., Logging and Soil Erosion: an Examination of The Effects of Logging On Soil Erosion in The Rain Forest of Ulu Segama, Eastern Sabah. BSc Dissertation. University of Manchester, Manchester, UK, 1990.

[3] Bruijnzeel, L.A., 1992. Managing Tropical Forest Watersheds for Production: where contra-dictionary theory and practice co-exist. in: Wise Management of Tropical forests, pp. 37-75. Oxford Forestry Institute, Oxford, UK.

[4] Cosandey, C., Andreassian, V., Martin, C., Didon-Lescot, J.F., Lavabre, J., Folton, N., Mathys, N., Richard, D., The Hydrological Impact of The Mediterranean Forest: a review of French research. J Hydrol (Amst) 301(1), pp. 235-249, 2005.

[5] Chaves, J., Neill, C., Gemer, S., Neto, S.G., Krusche, A., Elsenbeer, H., Land Management Impacts on Runoff Sources in Small Amazon Watersheds. Hydrol Process 22(12), pp. 1766-1775, 2008.

[6] Douglas, I., Predicting Road Erosion Rates in Selectively Logged Tropical Rain Forests. Proceedings of Symposium HS01 held during IUGG2003 at Sapporo, July 2003. IAHS Publ. no. 279, pp. 199-205. 2003.

[7] Duran Zuazo, V.H., Impact of Vegetation Cover on Runoff and Soil erosion at Hillslope Scale in Lanjaron, Spain. The Environmentalist, 24, pp. 39-48, 2004.

[8] Hartanto, H., Prabhu, R., Widayat, A.S.E., Asdak, C., Factors Affecting Runoff and Soil Erosion: Plot-level Soil Loss Monitoring for Assessing Sustainability of Forest Management. Journal of Forest Ecology and Management. Volume 180. Issues 1-3, pp. 361-374, 2003.

[9] Hendrison, J., Damage-controlled Logging in Managed Tropical Rainforest in Suriname. PhD thesis, Agricultural University Wageningen, The Netherlands, 1990.

[10] Huang, C. And Laflen, J.M., Seepage and Soil erosion for a Clay Loam Soil. Soil Sci. Soc. Am. J. 60, pp. 408-416, 1996.

[11] Huang, M., Zhang, L., and Gallichand, J., Runoff Responses to Afforestation in a Watershed of the Loess Plateau, China. Hydrol Process 17(13), pp. 2599-2609, 2003.

[12] Jordan, C.F., Nutrient cycling in tropical forest ecosystems. Wiley, Chichester, 1985. 
[13] Klöcking, B., Haberlandt, U., Impact of Landuse Changes on Water Dynamics - a Case Study in Temperate Meso and Macroscale River Basin. Phys Chem Earth 27, pp. 619-629, 2002.

[14] Lal, R., Deforestation of Tropical rainforest and Hydrological Problems. In: Lal, R., Russell, E.W. (eds.), Tropical Agricultural Hydrology. Wiley, New York, pp. 131-140, 1981.

[15] Montagnini, F. and Jordan, C.F., Tropical Forest Ecology. The basis for conservation and management. Springer, The Netherlands, pp. 40-53. 2005.

[16] Na'iem, M. and Faridah, E., Model of Intensive Enrichment Planting (TPTII). in: A. Rimbawanto (eds.), Silviculture Systems of Indonesia's Dipterocarps Forest Management A Lesson Learned. Faculty of Forestry Gadjah Mada University and ITTO. Technical Report: ITTO Project PD 41/00 Rev. 3 (F,M), pp. 25-36, 2006.

[17] Nussbaum, R. and Hoe, A.L., Rehabilitation of Degraded Sites In LoggedOver Forest Using Dipterocarps. in: A. Schulte dan D. Schone (eds.), Dipterocarps Forest Ecosystem. Towards Sustainable Management. World Scientific Publishing, Singapura, pp. 446-463, 1996.

[18] Nussbaum, R., Anderson, J., and Spencer, T., Planting Dipterocarps For Rehabilitation of Log Landings and Skid Trails in Sabah, Malaysia. in: S. Appanah dan K.C. Khoo (eds.), Proceedings of The Fifth Round-Table Conference on Dipterocarps. Chiang Mai, pp. 299-315, 1996.

[19] Osuji, G.E., Okon, M.A., Chukwuma, M.C., and Nwarie, I.I., Infiltration Characteristics of Soils under Selected Land Use Practices in Owerri, Southeastern Nigeria. World Journal of Agricultural Sciences 6 (3), pp. 322-326, 2010.

[20] Robinson, M., et al., Studies of The Impact of Forest on Peak Flows and Baseflows: a European Perspective. For Ecol Manage 186, pp. 85-97, 2003.

[21] Ruslan, M., and Manan, S., The effect of Skidding Roads on Soil Erosion and Runoff in the Forest Concession of Pulau Laut, South Kalimantan, Indonesia. (in Indonesia language). Proceeding of Seminar on Hydrology and Watershed Management, Surakarta, Indonesia, pp. 169-194, 1980.

[22] Stadtmueller, T., Soil Erosion in East Kalimantan, Indonesia. Proceedings of the Fiji Symposium. IAHS-AISH Publ. No. 192, pp. 221-230. 1990.

[23] Suryatmojo, H., The Effect of Line Planting Toward Infiltration. Proceeding of International Seminar "Research on Plantation Forest Management : Challenges and Opportunities", Bogor. 2009.

[24] Suryatmojo, H., Kosugi, K., Mizuyama, T., Nugroho, P., and Hakim, A.R., Water Balance in Tropical Rain Forest with Selective Cutting and Line Planting Treatment. Proceeding of International Conference "Sustainable Future for Human Security”, Kyoto University. Japan, 2010.

[25] Toy, T.J., Foster, G.R. and Renard, K.G., Soil Erosion: Processes, Prediction, Measurement, and Control. John Wiley \& sons, Inc., New York, pp. 25-52. 2002. 
[26] Wu, W., Hall, C.A.S., Scatena, F.N., Modelling the Impact of Recent Landcover Changes on The Stream Flows in Northeastern Puerto Rico. Hydrol Process 21(21), pp. 2944-2956, 2007.

[27] Widiyatno, Suryatmojo, H., Purnomo, S., Prelimenary Evaluation of Soil Fertility Status at Silviculture System "Tebang Pilih tanam Indonesia (TPTII)" at PT Sari Bumi Kusuma. Research Report (unpublished). Faculty of Forestry, Gadjah Mada University, Yogyakarta, Indonesia, 2010.

[28] Van Der Plas, M.C. and Bruijnzeel, L.A., Impact of Mechanized Selective Logging of Rainforest on Topsoil Infiltrability in the Upper Segama Area, Sabah, Malaysia. Hydrology of Warm Humid Regions. IAHS Publ. no. 216, pp. 203-211. 1993. 